\title{
GMR
}

\section{Genetic diversity of high performance cultivars of upland and irrigated Brazilian rice}

\author{
G.R.C. Coelho' ${ }^{1}$ C. Brondani ${ }^{1}$, L.V. Hoffmann', P.A.M.R. Valdisser', \\ T.C.O. Borba ${ }^{1}$, J.A. Mendonça ${ }^{1}$, L.A. Rodrigues ${ }^{1}$ and I.P.P. de Menezes $^{2}$ \\ ${ }^{1}$ Laboratório de Biotecnologia Vegetal, Embrapa Arroz e Feijão, \\ Santo Antônio de Goiás, GO, Brasil \\ ${ }^{2}$ Laboratório de Genética Molecular, Instituto Federal Goiano, \\ Urutaí, GO, Brasil \\ Corresponding author: G.R.C. Coelho \\ E-mail: gesimaria.coelho@embrapa.br
}

Genet. Mol. Res. 16 (3): gmr16039793

Received August 11, 2017

Accepted August 21, 2017

Published September 21, 2017

DOI http://dx.doi.org/10.4238/gmr16039793

Copyright (C) 2017 The Authors. This is an open-access article distributed under the terms of the Creative Commons Attribution ShareAlike (CC BY-SA) 4.0 License.

ABSTRACT. The objective of this study was to analyze the diversity and discrimination of high-performance Brazilian rice cultivars using microsatellite markers. Twenty-nine rice cultivars belonging to EMBRAPA Arroz e Feijão germplasm bank in Brazil were genotyped by 24 SSR markers to establish their structure and genetic discrimination. It was demonstrated that the analyzed germplasm of rice presents an expressive and significant genetic diversity with low heterogeneity among the cultivars. All 29 cultivars were differentiated genetically, and were organized into two groups related to their upland and irrigated cultivation systems. These groups showed a high genetic differentiation, with greater diversity within the group that includes the cultivars for irrigated system. The genotyping data of these cultivars, with the morphological e phenotypical data, are valuable information to be used by rice breeding programs to develop new improved cultivars.

Key words: Genetic diversity; Cultivar discrimination; Genetic resources; SSR 


\section{INTRODUCTION}

Rice (Oryza sativa L.), one of the world's most cultivated cereals, is considered a staple of the diet of more than half the world population, with a huge socioeconomic significance (Cheng et al., 2017). World rice production has doubled over the past 25 years due to the use of advanced technologies such as new varieties with higher yields and better management practices (IRRI, 2017). However, estimates from the Food and Agriculture Organization of the United Nations indicate that rice production is expected to double with the aim to fulfil the world population needs over the next 50 years (Santos et al., 2006). The need for development of cultivars with greater productive potential stability of production is, therefore, evidenced.

Plant breeding performed by crossings among conventional varieties represents a good strategy to maximize productivity and maintain grain quality (Miranda et al., 2003; Zeng et al., 2017), as well as to reduce unwanted segregation. The available genetic diversity is an important component for the success of breeding programs favoring the selection of appropriate parents for crossings resulting on heterosis and for recombination (Breseghello and Coelho, 2013). Thus, detailed knowledge of the genetic divergence of known high-yield rice cultivars may increase the chance of developing new cultivars with higher productive capacity, resistance to diseases and pests, high grain quality, and adaptation to new environments (Yap et al., 2016; Zeng et al., 2017).

Historically, rice is one of the oldest domesticated cereals. However, official breeding programs for this crop in Brazil only began in the 1930's. Then, the rice crop went through successive stages of selections and evaluations, producing, over the years, several cultivars of high performance and with advantages over those already existing in the market (Soares et al., 2004). In the period from 1983 to 2005, Embrapa Arroz e Feijão, and partner institutions, launched dozens of cultivars, recommended for different Brazilian regions (Breseghello et al., 1998; Abadie et al., 2005). Although there is a high proportion of parent-sharing in the rice cultivar development process, there is a morphological variation between them (Silva et al., 1999; Bueno et al., 2012), as for example cultivars that share two parents, as BR4 with the cultivars Emcapa and BRSMT Vencedora, and BRSM 1 with Jequitibá.

The narrow genetic base of the rice lines and cultivars, already discussed by several authors (Bonow et al., 2001; Pereira and Cruz, 2003; Abadie et al. 2005) has caused concern to the researchers due to the reduction of effective recombination and genetic gains. This may contribute to vulnerability to new pests, diseases and environmental changes, as well as to limit productivity levels (Abadie et al., 2005). Therefore, evaluating the genetic diversity and discrimination of the germplasm available is important to increase the efficiency of rice breeding programs.

Molecular markers are successfully used in selection of distinct genotypes for breeding, in order to increase the number of recombination events, resulting in new allelic combinations and greater chance of obtaining superior genotypes (Pereira et al., 2008). Microsatellite markers (SSR) are useful in the characterization of cultivars due to their reproducibility, multiallelism, codominant inheritance and good genome coverage, allowing the genetic discrimination even in related cultivars (Guichoux et al., 2011). SSRs have been used in the evaluation of diversity and the genetic relationship in several crops of agronomic interest, such as wheat (Mir et al., 2012), cotton (Menezes et al., 2010), maize (Qi-Lun et al., 2008), alfalfa (Flajoulot et al., 2005), soya (Brown-Guedira et al., 2000), beans (Cabral et al., 2011), and rice (Borba et al., 2009; Wei et al., 2009).

Genetics and Molecular Research 16 (3): gmr16039793 
The objective of this study was to determine, through the use of microsatellite markers, the structure and genetic diversity of high performance rice cultivars, commercially released within the period from 1983 to 2005, and indicated for upland and irrigated cultivation systems.

\section{MATERIAL AND METHODS}

\section{Vegetable samples and DNA extraction}

A total of 29 rice cultivars of high agronomic performance, developed and released by both private and public institutions in the period between 1983 and 2005 and recommended for several regions of the country, were analyzed. Accessions of these cultivars are stored in the germplasm bank of Embrapa Arroz e Feijão, and are available upon request (Table 1). Four plants per cultivar were analyzed separately, totaling 116 plants. The extraction of genomic DNA was obtained from young leaves according to the CTAB protocol, described by Brondani et al. (1998).

\section{Amplification of fragments}

A total of 24 microsatellite primer pairs were used for genotyping in a multiplex amplification system (Table 2). The selection of these markers was based on their discriminative power, simple amplification pattern, and for having independent segregation (Borba et al., 2009). The reactions were prepared with Multiplex PCR Kit (Qiagen) at a final volume of $5 \mu \mathrm{L}$, containing $3 \mathrm{ng}$ DNA, 1X Master mix, Q-solution $0.5 \mathrm{X}$ various primer pairs concentrations (forward and reverse) according to Borba et al. (2009), and RNase-free water. The amplification reactions were conducted in a thermocycler 9700 (Life Technologies) with the following schedule: initial denaturation at $95^{\circ} \mathrm{C}$ for $15 \mathrm{~min}$, followed by 40 amplification cycles, with each cycle consisting of denaturation at $94^{\circ} \mathrm{C}$ for $30 \mathrm{~s}$, annealing at $56^{\circ} \mathrm{C}$ for $90 \mathrm{~s}$, and extension at $72^{\circ} \mathrm{C}$ for $90 \mathrm{~s}$; and, finally, a final extension at $72^{\circ} \mathrm{C}$ for $10 \mathrm{~min}$. The amplification products were separated by capillary electrophoresis on an ABI 3100 DNA sequencer (Life Technologies). Locus genotyping (in $\mathrm{bp}$ ) was performed through the GeneMapper 3.5 program (Applied Biosystems), using the ROX 500 internal molecular weight marker (Life Technologies).

\section{Data analysis}

The descriptive analysis of the cultivars genetic diversity was carried out using estimates of the allelic frequencies of the polymorphic loci, number of alleles per locus $\left(N_{\mathrm{A}}\right)$, number of private alleles (Ap - alleles found in a single plant or cultivar), gene diversity or expected heterozygosity $\left(H_{\mathrm{E}}\right)$ and observed heterozygosity $\left(H_{\mathrm{O}}\right)$, fixation index $\left(F_{\mathrm{IS}}\right)$, probability of genetic identity (PI) and probability of paternity exclusion (PE) from single locus and multilocus using the GenAlEx v6.5 program (Peakall and Smouse, 2012).

Genetic divergence (GD) among cultivar pairs was calculated based on Wright's modified Roger's coefficient, using the NTSYS program. The GD matrix was then used to design a dendrogram employing neighbor joining clustering method using the MEGA7 program. The genetic structure was analyzed from the Bayesian model implemented by the program Structure (Pritchard et al., 2000), with the "admixture" options and correlated allelic

Genetics and Molecular Research 16 (3): gmr16039793 
Table 1. Main characteristics of 29 rice cultivars, released between the years 1983 to 2005, and the heterogeneity detected for the SSR markers.

\begin{tabular}{|c|c|c|c|c|c|c|}
\hline № & Cultivar & Year & Genealogy & Main characteristics & Cultivation system & SSR markers that detected heterogeneity \\
\hline 1 & BR4 & 1983 & IAC 5544/ Dourado Precoce & $\begin{array}{l}\text { Height of } 110 \mathrm{~cm}, 70 \text { days in average to flower, long grain class, } \\
\text { moderately resistant to blast (leaf and neck), brown leaf spot, grain spot, } \\
\text { and scald. }\end{array}$ & Upland & RM38, 4653, RM14 \\
\hline 2 & Encapa & 1983 & IAC 5544/ Dourado Precoce & $\begin{array}{l}\text { Height of } 115 \mathrm{~cm}, 80 \text { days in average to flower, long class, moderately } \\
\text { resistant to leaf and neck blast, brown leaf spot, grain spot, and scald. }\end{array}$ & Upland & $\begin{array}{l}\text { RM257, RM299, RM14, RM210, OG10, RM253, } \\
\text { RM207, RM55 }\end{array}$ \\
\hline 3 & Centro América & 1987 & $63-83 /$ IAC 125 & $\begin{array}{l}\text { Good grain spot resistance, early flowering, } 102 \text { spikelets per panicle, } \\
63.4 \% \text { of whole grains. }\end{array}$ & Upland & $\begin{array}{l}\text { RM38, 4653, OG106, RM257, RM171, RM231, } \\
\text { OG44, RM07, RM229, RM14, RM210, RM222, } \\
\text { RM309, RM253, RM207, RM252, RM11, } \\
\text { RM55, RM263, RM248 }\end{array}$ \\
\hline$\overline{4}$ & Mearim & 1989 & Mutant of OS 6 from Nigeria & $\begin{array}{l}\text { Height from } 100 \mathrm{~cm} \text { to } 110 \mathrm{~cm}, 77 \text { days in average to flower, long grain } \\
\text { class, moderately resistance to leaf and neck blast, and grain spot. } \\
\text { Susceptible to brown leaf spot. }\end{array}$ & Uppland & RM252, RM55 \\
\hline 5 & Rio Paraguai & 1992 & $\operatorname{IAC} 47 / 63-83$ & $\begin{array}{l}\text { Hight from } 94 \text { to } 139 \mathrm{~cm}, 84 \text { to } 90 \text { days in average to flower, long } \\
\text { grain class, moderately resistant to leaf and neck blast. Moderately } \\
\text { resistant to brown leaf spot and grain spot. }\end{array}$ & Upland & RM38, 4653, RM14, RM222, RM11 \\
\hline 6 & Acrefino & 1993 & Rustic/ Tapuripa & $\begin{array}{l}\text { Height of } 120 \mathrm{~cm}, 95 \text { days in average to flower, long class, moderately } \\
\text { lodging gesistant to moderately resistant to leaf and neck blast, brown } \\
\text { leaf spoto grain spot and scald. }\end{array}$ & Upland & RM14, RM210, RM55, RM248 \\
\hline 7 & Sapucai & 1994 & $\begin{array}{l}\text { P 901-22-7-3-2-1B/P 918-19-9-3-1-3-1//P } \\
\text { 918-25-1-4-2-3-IB/P 882-12-6-5-3-1-1 }\end{array}$ & $\begin{array}{l}\text { Height of } 80 \mathrm{~cm} .126 \text { grains per panicle. Moderately resistant to neck } \\
\text { blast. }\end{array}$ & Irrigated & $\begin{array}{l}\text { 4653, OG106, RM257, RM287, RM07, RM14, } \\
\text { RM222, RM55 }\end{array}$ \\
\hline 8 & BRSMT Vencedora & 2003 & IAC 5544/ Dourado Precoce & $\begin{array}{l}\text { Height of } 73 \mathrm{~cm}, 76 \text { days in average to flower, long-thin class, } \\
\text { moderately resistant to leaf and neck blast. Moderately susceptible to } \\
\text { brown leaf spot, grain spot and scald. }\end{array}$ & Upland & $\begin{array}{l}\text { RM38, 4653, OG44, RM07, RM229, RM14, } \\
\text { RM222, RM309 }\end{array}$ \\
\hline$\overline{9}$ & BRS Aroma & 2004 & $\begin{array}{l}\text { Basmati370/Lebonnet // CNA6874/ } \\
\text { CNA6682 }\end{array}$ & $\begin{array}{l}\text { Height of } 107 \mathrm{~cm}, 77 \text { days in average to flower, long-thin class. } \\
\text { Moderately yesistant to leaf and neck blast and brown spot. Moderately } \\
\text { susceptible to grain leaf spot and scald. }\end{array}$ & Upland & RM204, RM103, RM14 \\
\hline 10 & BRS Colosso & 2004 & $\begin{array}{l}\text { Keybonnet x Aimoré (double-haploid from } \\
\text { another culture) }\end{array}$ & $\begin{array}{l}\text { Height of } 96 \mathrm{~cm}, 77 \text { days in average to flower, long-thin class. } \\
\text { Moderately resistant to leaf and neck blast. Moderately susceptible to } \\
\text { brown leaf spot, grain spot and scald. }\end{array}$ & Upland & $\begin{array}{l}\text { RM210, RM207, RM252, RM } \\
\text { RM263, RM248 }\end{array}$ \\
\hline$\overline{11}$ & BRS MG Conai & 2004 & Confiança/ Aimoré & $\begin{array}{l}\text { Height of } 87 \mathrm{~cm}, 76 \text { days in average to flower, long-thin grain class. } \\
\text { Moderately resistant to leaf and neck blast. Moderately susceptible to } \\
\text { brown spot, grain spot and scald. }\end{array}$ & Upland & 4653, RM14, RM210 \\
\hline$\overline{12}$ & BRS MG Curinga & 2005 & $\begin{array}{l}\text { CT 9978-12-2-2P-4/CT 10037-56-4-M-4-1- } \\
\text { P-1//P5589-1-1-3P-1-1P/CT9356 }\end{array}$ & $\begin{array}{l}\text { Height of } 93 \mathrm{~cm}, 97 \text { days in average to flowering, long-thin grain class. } \\
\text { Moderately resistant to leaf and neck blast. Moderately susceptible to } \\
\text { brown leaf spot, grain spot and scald }\end{array}$ & Upland & 4653, RM257, OG10, RM248 \\
\hline$\overline{13}$ & MG-1 & 1984 & P $1217 \times$ P1232 & $\begin{array}{l}\text { Height from } 855 \text { to } 100 \mathrm{~cm}, 90 \mathrm{0} \text { to } 115 \text { days in average to flower, long- } \\
\text { thin grain class. Resistant to eaf blast, moderately resistant to neck } \\
\text { blast, brown leaf spot, grain spot and scald. }\end{array}$ & Irrigated & $\begin{array}{l}\text { RM38, 4653, OG106, RM257, RM287, OG44, } \\
\text { RM07, RM229, RM14, RM210, OG10, RM309, } \\
\text { RM207, RM252, RM11, RM248 }\end{array}$ \\
\hline 14 & MG-2 & 1984 & BG $66 \times$ IR 26 & \begin{tabular}{|l} 
Height from 85 to $100 \mathrm{~cm}, 90$ to 115 days in average to flower, long- \\
thin grain class. Resistant to leaf blast. Moderately resistant to neck \\
blast, grain spot and scald. Moderately susceptible brown leaf spot.
\end{tabular} & Irrigated & RM38 \\
\hline 15 & Capivari & 1994 & CNA 5751 (CIAT P 4145 F3-31) & $\begin{array}{l}\text { Height of } 80 \mathrm{~cm}, 130 \text { days in average to } \\
\text { Moderately resistant to leaf and neck bl }\end{array}$ & Irrigated & $\begin{array}{l}\text { RM171, RM287, OG44, RM07, RM299, RM222, } \\
\text { RM207, RM248 }\end{array}$ \\
\hline$\overline{16}$ & Ajuricaba & 1986 & BG 90-2//4440/Colombia 1 & $\begin{array}{l}\text { Height from } 100 \text { to } 115 \mathrm{~cm}, 75 \text { to } 95 \text { days in average to flower, long } \\
\text { grain class. Moderately resistant to leaf and neck blast, brown leaf spot, } \\
\text { grain spot, scald. }\end{array}$ & Irrigated & $\begin{array}{l}\text { RM238, RM231, RM287, RM229, RM14, } \\
\text { RM210, RM222, RM309, RM11, RM263 }\end{array}$ \\
\hline 17 & Franciscano & 1988 & Cica 7 x F1(4440 x Pelita 1/1) & $\begin{array}{l}\text { Height of } 92 \mathrm{~cm}, 105 \text { to } 115 \text { days to flower, long-thin grain class. } \\
\text { Moderately resistant to leaf and neck blast, brown leaf spot, grain spot, } \\
\text { scald. }\end{array}$ & Irrigated & RM287, RM14 \\
\hline$\frac{18}{19}$ & $\frac{\text { BRMS 1 }}{\text { BRMS 2 }}$ & 1989 & \begin{tabular}{|l} 
BR-Irga409/CICA 9 \\
Chianung SEN 12/R 22
\end{tabular} & $\begin{array}{l}\text { resistant, } 58.7 \% \text { of whole grains } \\
\text { rains. Resistant to lodging, } \\
\text { t. }\end{array}$ & Ifrrigated & $\begin{array}{l}\text { RM103, RM231, RM14, RM222, RM309 } \\
\text { RM17, RM231, RM287, RM07, RM229, } \\
\text { RM253, RM248 }\end{array}$ \\
\hline$\overline{20}$ & Aliança & 1990 & 4440/BG90-2/TETEP & $\begin{array}{l}\text { Height of } 90 \mathrm{~cm}, 115 \text { days in average to flower, long-thin grain class. } \\
\text { Moderately susceptible to leaf and neck blast. Moderately resistant to } \\
\text { brown leaf spot, grain spot and scald }\end{array}$ & Irrigated & RM07, RM248 \\
\hline 21 & BR IPA 1 & 1992 & Nay Lamp/R 480/TETEP & Lodging 1 & Irrigated & RM257, RM14 \\
\hline$\overline{22}$ & Javaé & 1993 & P 3085///R 5853-1 18-5/R 19743-25-2-2-3-1 & $\begin{array}{l}\text { Height from } 90 \text { to } 100 \mathrm{~cm}, 80 \text { days in average to flower, long-thin grain } \\
\text { class. Resistant to leaf blast, susceptible neck blast, moderately resistant } \\
\text { to brown leaf spot, grain spot and scald. }\end{array}$ & Irrigated & $\begin{array}{l}\text { 4653, RM287, OG44, RM07, RM299, RM14, } \\
\text { RM263, RM248 }\end{array}$ \\
\hline$\overline{23}$ & Urucuia & 1994 & Nanicão/ cica 8/MG1 & $\begin{array}{l}123 \text { days in average to flower. Resistant to leaf and } \\
\text { t. }\end{array}$ & Irrigated & RM38, RM14, RM55 \\
\hline$\overline{24}$ & Samburá & 1995 & Nanicão/ BG 90-2//MG1 & $\begin{array}{l}\text { Flowering around } 136 \text { days after planting, maturation cycle } 170 \text { days. } \\
\text { Moderately lodging resistant, resistant to leaf and neck, blast, brown } \\
\text { spot and moderately resistant to grain spot. }\end{array}$ & Lowland & $\begin{array}{l}\text { RM38, OG106, RM257, RM103, RM171, } \\
\text { RM231, RM287, OG44, RM07, RM229, RM14, } \\
\text { OG10, RM55, RM248 }\end{array}$ \\
\hline 25 & São Francisco & 1996 & 5732//3234/Costa Rica & $\begin{array}{l}\text { Height of } 80 \mathrm{~cm}, 100 \text { days to bloom, long-thin grain class. Moderately } \\
\text { resistant to leaf and neck blast, brown leaf spot, grain spot and scald. }\end{array}$ & Irrigated & RM07, RM207, RM11, RM248 \\
\hline 26 & Jequiti & 1997 & Cica 9/ BR-IRGA 409 & $\begin{array}{l}\text { Height of } 92 \mathrm{~cm}, 94 \text { days to bloom, long-thin grain } \\
\text { resistant to leaf and neck blast, brown leaf spot, gr }\end{array}$ & Irrigated & RMS \\
\hline 27 & $\begin{array}{l}\text { SCS BRS } 113 \text { Tio } \\
\text { Taka }\end{array}$ & 2002 & $\begin{array}{l}\text { CAN } 8644 \text { (CN-IRAT 4M/2/1-75-B-B-2-2- } \\
\text { B) }\end{array}$ & $\begin{array}{l}111 \text { days to bloom, long-thin grain class. Susceptible } \\
\text { ast. }\end{array}$ & Irrigated & RM14, RM248 \\
\hline$\overline{28}$ & \begin{tabular}{|l} 
BRS MG \\
OUROMINAS
\end{tabular} & 2002 & $17719,5739 \times$ IR21015-72-3-3-3-1 & $\begin{array}{l}\text { Height of } 90 \mathrm{~cm}, 94 \text { to } 105 \text { days to bloom, long-thin grain class. } \\
\text { Moderately susceptive to leaf and neck blast, brown spot, grain spot and } \\
\text { scald. }\end{array}$ & Irrigated & RM231, RM14, OG10, RM207, RM11, RM263 \\
\hline 29 & BRS MG Seleta & 2004 & CT 7415/P4743//CT 8154 & $\begin{array}{l}\text { Height of } 95 \mathrm{~cm}, 100 \text { to } 105 \text { days to bloom, long-thin grain class. } \\
\text { Moderately resistant to leaf and neck blast, grain spot and scald. } \\
\text { Resistant to brown leaf spot. }\end{array}$ & Irrigated & RM07, RM14, RM252 \\
\hline
\end{tabular}

frequencies. Ten runs were performed for the tested values of $K$ (1 to 10), with burn-in of 50,000 , followed by 500,000 interactions. The number of genetic groups $(\Delta K)$ was determined according to the method of Evanno et al. (2005), using the program Structure harvester (Earl and VonHoldt, 2012). The analysis of molecular variance (AMOVA) was performed to verify the partitioning of genetic variation between and within the cultivars, through the GenAlEx program (Peakall and Smouse, 2012). In this particular analysis, each allele was labeled with (1), when present, and (0) when absent. Later, an AMOVA was performed, based on the identification of the presence or absence of genetic structure by the Structure software, and the genetic diversity indexes were re-analyzed for the genetic structure found.

Genetics and Molecular Research 16 (3): gmr16039793 
Table 2. Microsatellite markers used in the evaluation of the 29 rice cultivars.

\begin{tabular}{|c|c|c|c|c|c|c|}
\hline Panel & Marker & Fluorescence & Amplitude (bp) & Motif & Chromosome & Authors \\
\hline 1 & 4653 & 6-FAM & $101-167$ & $(\mathrm{AAG})_{25}$ & 12 & Rangel et al., 2007 \\
\hline 1 & OG106 & 6-FAM & $175-249$ & $(\mathrm{CT})_{27}$ & 9 & Brondani et al., 2001 \\
\hline 1 & RM103 & NED & $308-344$ & $(\mathrm{GAA})_{5}$ & 6 & Temnykh et al., 2000 \\
\hline 1 & RM257 & NED & 104-192 & $(\mathrm{CT})_{24}$ & 9 & Chen et al., 1997 \\
\hline 1 & RM07 & PET & $170-186$ & $(\mathrm{GA})_{19}$ & 3 & Panaud et al., 1996 \\
\hline 1 & RM287 & PET & $97-117$ & $(\mathrm{GA})_{21}$ & 11 & Temnykh et al., 2000 \\
\hline 1 & RM38 & VIC & $236-264$ & $(\mathrm{GA})_{16}$ & 8 & Chen et al., 1997 \\
\hline 1 & RM204 & VIC & $102-174$ & $(\mathrm{CT})_{44}$ & 6 & Chen et al., 1997 \\
\hline 2 & RM210 & 6-FAM & $138-160$ & $(\mathrm{CT})_{23}$ & 8 & Chen et al., 1997 \\
\hline 2 & RM222 & 6-FAM & $199-223$ & (CT) 18 & 10 & Chen et al., 1997 \\
\hline 2 & RM253 & NED & $113-143$ & $(\mathrm{GA})_{25}$ & 6 & Chen et al., 1997 \\
\hline 2 & RM309 & NED & $161-173$ & $(\mathrm{GT})_{13}$ & 12 & Temnykh et al., 2000 \\
\hline 2 & RM171 & PET & $325-349$ & $(\mathrm{GATG})_{5}$ & 10 & Akagi et al., 1996 \\
\hline 2 & RM231 & PET & 168-194 & $(\mathrm{CT})_{16}$ & 3 & Chen et al., 1997 \\
\hline 2 & RM14 & VIC & $173-246$ & $(\mathrm{GA})_{18}$ & 1 & Panaud et al., 1996 \\
\hline 2 & OG10 & VIC & $88-124$ & $(\mathrm{CT})_{29}$ & 9 & Brondani et al., 2001 \\
\hline 3 & RM207 & 6-FAM & $104-142$ & $(\mathrm{CT})_{25}$ & 2 & Chen et al., 1997 \\
\hline 3 & RM252 & 6-FAM & $192-276$ & $(\mathrm{CT})_{19}$ & 4 & Chen et al., 1997 \\
\hline 3 & RM11 & NED & $100-142$ & $(\mathrm{GA})_{17}$ & 7 & Panaud et al., 1996 \\
\hline 3 & RM55 & NED & $217-237$ & $(\mathrm{GA})_{17}$ & 3 & Chen et al., 1997 \\
\hline 3 & OG44 & PET & $157-175$ & $\begin{array}{c}(\mathrm{CT})_{4-23 \mathrm{bp}-} \\
(\mathrm{CT})_{22}-(\mathrm{GT})_{4}(\mathrm{GCC})_{6}\end{array}$ & 3 & Brondani et al., 2001 \\
\hline 3 & RM229 & PET & $82-132$ & $\begin{array}{c}(\mathrm{TC})_{11} \\
(\mathrm{CT})_{5} \mathrm{C}_{3}(\mathrm{CT})_{5}\end{array}$ & 11 & Chen et al., 1997 \\
\hline 3 & RM248 & VIC & $79-109$ & $(\mathrm{CT})_{25}$ & 7 & Chen et al., 1997 \\
\hline 3 & RM263 & VIC & $145-201$ & $(\mathrm{CT})_{34}$ & 2 & Chen et al., 1997 \\
\hline
\end{tabular}

\section{RESULTS AND DISCUSSION}

All the 24 microsatellite markers analyzed were polymorphic, totaling 163 alleles, with a mean of 6.83 alleles per locus, ranging from two (RM309) to ten alleles (4653, OG106 and RM248) per locus of SSR (Table 3). Similar numbers of alleles per locus (8.0 and 6.6) were found in accessions from an Indian germplasm bank of aromatic rice and traditional Cuban rice varieties, respectively (Roy et al., 2015). When compared for a germplasm formed of rice lines from different countries was lower (12 per locus) (Borba et al., 2010).

The genetic diversity calculated in the 29 rice cultivars studied was high $\left(H_{\mathrm{E}}=0.675\right.$ \pm 0.032 ), ranging from 0.354 in the locus OG44 to 0.846 in the locus RM257. Roy et al. (2015), Borba et al. $(2009,2010)$ also found expected average heterozygosity close to that 
found in the present study in different accessions of the germplasm bank in India (0.67) and foreign, traditional and improved accessions from the Embrapa Rice Core Collection (0.67). Although the material presents a high level of diversity, it also presents low levels of observed heterozygosity evidenced by the average value of $H_{\mathrm{O}}=0.009( \pm 0.003)$. It was zero in 15 of the 24 SSRs locus evaluated, and in the others loci ranged from 0.009 in the SSR locus 4653, RM171, and RM222, to 0.128 in loci RM287. These low $H_{\mathrm{O}}$ values corroborate with the predominantly autogamous reproductive system of the species, also indicated by the high fixation index, $F_{\text {IS }}=0.982( \pm 0.008)$. These values of $H_{\mathrm{E}}, H_{\mathrm{O}}$ and $F_{\text {IS }}$ demonstrate that the genetic diversity found is organized in homozygous genotypes, indicating the purity of the cultivars released and thus their homogeneity and genetic stability.

Table 3. Descriptive analysis for SSR markers in 29 rice cultivars.

\begin{tabular}{|c|c|c|c|c|c|c|c|}
\hline Loci & Size (bp) & $N_{\mathrm{A}}$ & $H_{\mathrm{E}}$ & $H_{\mathrm{O}}$ & $F_{\text {IS }}$ & PI & $\mathrm{PE}$ \\
\hline RM204 & $106-176$ & 6 & 0.359 & 0.026 & 0.928 & 0.430 & 0.348 \\
\hline RM038 & $240-261$ & 8 & 0.764 & 0.000 & 1.000 & 0.079 & 0.783 \\
\hline 4653 & 084-168 & 10 & 0.784 & 0.009 & 0.989 & 0.074 & 0.789 \\
\hline OG106 & $197-231$ & 10 & 0.841 & 0.000 & 1.000 & 0.046 & 0.852 \\
\hline RM257 & $142-174$ & 9 & 0.846 & 0.000 & 1.000 & 0.044 & 0.856 \\
\hline RM103 & $328-336$ & 4 & 0.576 & 0.000 & 1.000 & 0.255 & 0.452 \\
\hline RM171 & $321-344$ & 4 & 0.574 & 0.009 & 0.985 & 0.276 & 0.415 \\
\hline RM231 & $166-192$ & 6 & 0.807 & 0.000 & 1.000 & 0.068 & 0.788 \\
\hline RM287 & $101-114$ & 5 & 0.667 & 0.172 & 0.974 & 0.174 & 0.580 \\
\hline OG044 & $153-171$ & 5 & 0.354 & 0.052 & 0.854 & 0.441 & 0.327 \\
\hline RM007 & $166-184$ & 7 & 0.777 & 0.000 & 1.000 & 0.085 & 0.751 \\
\hline RM229 & 096-128 & 7 & 0.744 & 0.000 & 1.000 & 0.109 & 0.698 \\
\hline RM014 & 169-191 & 8 & 0.483 & 0.052 & 0.893 & 0.300 & 0.459 \\
\hline RM210 & $138-164$ & 8 & 0.640 & 0.000 & 1.000 & 0.158 & 0.646 \\
\hline OG010 & $092-126$ & 6 & 0.777 & 0.000 & 1.000 & 0.089 & 0.732 \\
\hline RM222 & $203-225$ & 7 & 0.812 & 0.009 & 0.989 & 0.064 & 0.798 \\
\hline RM309 & $169-171$ & 2 & 0.459 & 0.000 & 1.000 & 0.399 & 0.268 \\
\hline RM253 & $131-141$ & 4 & 0.447 & 0.000 & 1.000 & 0.340 & 0.405 \\
\hline RM207 & $116-144$ & 8 & 0.829 & 0.000 & 1.000 & 0.054 & 0.828 \\
\hline RM252 & $194-254$ & 7 & 0.664 & 0.000 & 1.000 & 0.174 & 0.589 \\
\hline RM011 & $119-144$ & 7 & 0.716 & 0.017 & 0.976 & 0.112 & 0.710 \\
\hline RM055 & 218-299 & 7 & 0.724 & 0.017 & 0.976 & 0.108 & 0.717 \\
\hline RM263 & $155-201$ & 8 & 0.802 & 0.000 & 1.000 & 0.069 & 0.787 \\
\hline RM248 & 080-105 & 10 & 0.756 & 0.000 & 1.000 & 0.086 & 0.767 \\
\hline Total & - & 163 & - & - & - & $4.3 \times 10^{-22}$ & 1.00 \\
\hline Mean & & $6.83( \pm 0.42)$ & $0.675( \pm 0.032)$ & $0.009( \pm 0.003)$ & $0.982( \pm 0.008)$ & - & - \\
\hline
\end{tabular}

$N_{\mathrm{A}}=$ number of alleles; $H_{\mathrm{E}}=$ expected heterozygosity; $H_{\mathrm{O}}=$ observed heterozygosity; $\mathrm{PI}$ = probability of genetic identity; $\mathrm{PE}=$ probability of paternity exclusion. 
The heterogeneity of the cultivars was evaluated considering genotype variation within the four individual plants per cultivar, for each locus. All rice cultivars included in this study had at least one heterogeneous SSR locus with heterogeneity. The number of heterogeneous loci ranged until 20, as in the case of the "Centro América cultivar (Table 1). For 11 of the 29 cultivars, the heterogeneity was attributed to heterozygotes observed in one or two locus. For the other cultivars the cause of heterogeneity were homozygotes for different alleles in the different plants of the cultivar, corroborating with the low value of $H_{\mathrm{O}}$.

The cultivars Centro América, Ajuricaba, MG-1 and Samburá presented higher number of SSR locus indicating heterogeneity, with 20 (83\%), 17 (71\%), $16(67 \%)$, and 14 $(58 \%)$ of the analyzed markers, respectively. The genetic variation found within each plant and cultivar corresponds to about 1.0 and $20 \%$, respectively, as indicated by AMOVA, while $80 \%$ is concentrated among the cultivars, presenting a high genetic differentiation value $\left(F_{\mathrm{ST}}\right)$ of 0.796 (P value $<0.01$ for 9999 permutations). Additionally, no identical cultivars were observed, therefore the 24 SSRs presented a high discriminatory power. This is reinforced by the average PI value (4.4 x 10-22) and multi locus PE value (1.00), as well as single locus values, which ranged from 0.044 (locus RM257) to 0.441 (loci OG044), and 0.268 (locus RM309) to 0.856 (locus RM257), respectively (Table 3).

Thirty-three alleles were private (Ap), those that were present only in a specific cultivar. This total Ap represents $20 \%$ of the amplified alleles. The cultivars BRS Aroma, BRS Colosso, and MG-1 presented the highest number of private alleles, with five, four, and four of these 33 private alleles, respectively (Table 4 ). The greater the number of private alleles found in a cultivar, the more divergent its origin, thus demonstrating a broader genetic base of the material analyzed, therefore relevant to breeding programs.

\begin{tabular}{|c|c|c|}
\hline Cultivars & $\mathrm{A}_{\mathrm{P}}$ & Loci SSR_allele size (bp) \\
\hline Acrefino & 2 & RM 204_176; RM 257_174 \\
\hline BR Aroma & 5 & RM204_152 e 154; RM38_257; 4653_146; RM103_334 \\
\hline BRS Colosso & 4 & RM229_128; RM210_140; RM253_131; RM252_246 \\
\hline BRS MG Curinga & 1 & OG10_100 \\
\hline Emcapa & 1 & RM229_126 \\
\hline BRMS2 & 1 & OG10_126 \\
\hline Ajuricaba & 1 & RM210_164 \\
\hline Aliança & 1 & RM07_180 \\
\hline Capivari & 1 & RM171_321 \\
\hline BR IPA 101 & 1 & RM263_185 \\
\hline Javaé & 2 & RM11_142; RM263_183 \\
\hline MG-1 & 4 & OG106_209; RM257_154;OG44_155;RM248_095 \\
\hline São Francisco & 1 & RM207_124 \\
\hline Sapucaí & 2 & OG106_205; RM55_299 \\
\hline BRS MG Seleta & 2 & RM252_254; RM248_105 \\
\hline Urucuia & 1 & RM14_185 \\
\hline MG-2 & 1 & RM204_118 \\
\hline BRSMT Vencedora & 2 & 4653_156; RM210_158 \\
\hline Total & 33 & \\
\hline
\end{tabular}

Genetics and Molecular Research 16 (3): gmr16039793 
The 29 rice cultivars showed an intermediate genetic divergence, as indicated by the estimated mean GD value of 0.535 , and $68 \%$ of the pairwise comparisons between genotypes with GD greater than or equal to 0.50 . The lowest value for the genetic distance $(0.184)$ was found between cultivars Aliança and Urucuia, both cultivars of the upland crop system, while the highest distance value (0.666) was detected between cultivars BR4 and BRSMG Seleta, one of the cultivars of an upland system and another of an irrigated system, respectively. The evaluated cultivars were organized into two groups, both by neighbor joining cluster analysis (Figure 1) and Bayesian model (Figure 2). The green group (Figure 2) was formed by 9 cultivars of the upland system, and the red group by 18 cultivars of an irrigated system and 1 of the upland (Mearim). The cultivar Acrefino forms an intermediate branch to the upland and irrigated pools. The cultivar Acrefino was developed for cultivation in the state of Acre for the upland cultivation system, but is favored by an average rainfall of $2000 \mathrm{~mm} / \mathrm{year}$.

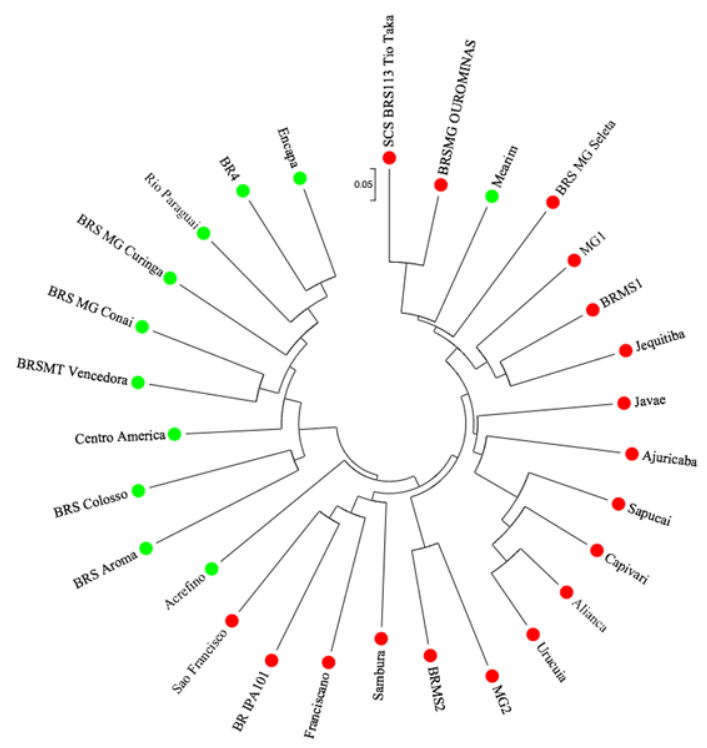

Figure 1. Dendrogram of 29 elite rice cultivars, based on Roger's distance modified using the neighbor-joining method. The red spots represent irrigated rice cultivars, and the green spots represent rice cultivars of the upland system.

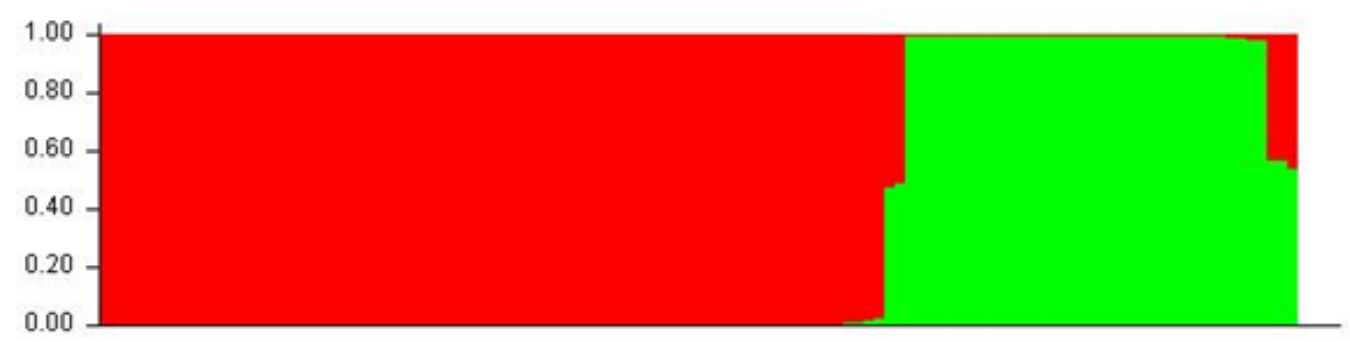

Figure 2. Genetic structure of the 116 rice plants representing 29 cultivars. Cultivars belonging to the irrigated cropping system are evidenced in red and cultivars from upland systems, in green.

Genetics and Molecular Research 16 (3): gmr16039793 
In the analysis by the Bayesian model, it was also verified the formation of two groups $(\Delta \mathrm{K}=2)$, identical to those observed in the dendrogram. The cultivars were classified into each group indicated by the upland or irrigated system, with high values of shared ancestry, with mean value of 0.997 , except for the Mearim, an upland cultivar classified, but ascribed to the irrigated gene pool group in both cluster analyzes. The Acrefino cultivar and one of the four plants of the Central America cultivar presented intermediate values [0.477 (A), 0.523 (B), 0.458 (A), 0.542 (B), respectively] of shared ancestry, indicating admixture in similar proportions of both groups (Figure 2). Excluding the admixture plants, the structuring of the cultivars $(\Delta \mathrm{K}=2)$ defined in the cluster analyzes was significantly elevated and different from zero, with a $F_{\text {ST }}$ value of $0.349(\mathrm{P}<0.05)$.

A genetic structure similar and organized for cultivation (irrigated or upland) system was observed by Borba et al. (2010), when analyzed accessions from breeding programs of Brazil and other countries. The stratification observed demonstrated the driven and independent selection in breeding programs for each system of cultivation, that historically is based according the distinct genetic pool from indicate (irrigated) and japonica (upland) subspecies.

The diversity was greater within group composed by most of the irrigated rice cultivars, represented in red in Figure $2\left(N_{\mathrm{A}}=114, \mathrm{Ap}=73, H_{\mathrm{E}}=0.547\right)$, when compared to the group of the upland rice represented in green $\left(N_{\mathrm{A}}=85, \mathrm{Ap}=44, H_{\mathrm{E}}=0.475\right)$ (Table 5). Similar results were found by Borba et al. (2010) both in foreign and Brazilian accessions. Probably this was due to the use of genetically related parents in the upland rice group (japonica subspecies), which has narrow genetic variability in relation to indicate subspecies (Yu et al., 2013).

Table 5. Descriptors of genetic diversity of Brazilian rice cultivars released in the 1980's, 1990's, and 2000's organized in upland and irrigated groups.

\begin{tabular}{l|l|c|c|c|c|c|c}
\hline Cropping system & Period & $\mathrm{S}$ & $\mathrm{P} \%$ & $N_{\mathrm{A}}$ & $\mathrm{Ap}$ & $H_{\mathrm{O}}$ & $H_{\mathrm{E}}$ \\
\hline \multirow{3}{*}{ Upland } & 1980 's & 4 & 70.8 & 59 & 4 & $0.008( \pm 0.006)$ & $0.332( \pm 0.053)$ \\
\cline { 2 - 8 } & 1990 's & 1 & 20.8 & 30 & 0 & $0.000( \pm 0.000)$ & $0.113( \pm 0.047)$ \\
\cline { 2 - 8 } & 2000 's & 4 & 83.3 & 68 & 14 & $0.008( \pm 0.008)$ & $0.433( \pm 0.055)$ \\
\hline \multirow{3}{*}{ Irrigated } & Subtotal & 9 & 91.7 & 85 & 44 & $0.007( \pm 0.004)$ & $0.475( \pm 0.049)$ \\
\hline & 1980 's & 9 & 100 & 91 & 20 & $0.010( \pm 0.006)$ & $0.560( \pm 0.036)$ \\
\cline { 2 - 8 } & 1990 's & 7 & 87.5 & 75 & 10 & $0.012( \pm 0.007)$ & $0.405( \pm 0.041)$ \\
\cline { 2 - 8 } & 2000 's & 3 & 62.5 & 49 & 2 & $0.003( \pm 0.003)$ & $0.304( \pm 0.056)$ \\
\hline & Subtotal & 19 & 100 & 114 & 73 & $0.010( \pm 0.004)$ & $0.547( \pm 0.036)$ \\
\hline
\end{tabular}

$\mathrm{S}=$ number of cultivars; $\mathrm{P} \%=$ proportion of polymorphic loci; $N_{\mathrm{A}}=$ number of alleles; $\mathrm{Ap}=$ number of private alleles; $H_{\mathrm{O}}=$ observed heterozygosity; $H_{\mathrm{E}}=$ expected heterozygosity. Each cultivar is represented by a pool of four plants.

In the temporal comparison of the genetic diversity descriptors, separately by cultivation system, in the 1980's, 1990's, and 2000's, there was a slight diversity increase in the cultivars of upland rice and a decline in the cultivars of irrigated rice (Table 5). The $H_{\mathrm{O}}$ was similarly low and declining among the decades for the cultivars of both cultivation systems, demonstrating the rigor to produce pure seeds of these cultivars. A high and significant genetic differentiation of the cultivars in both systems was observed (upland $F_{\mathrm{ST}}=0.326$ and irrigated $F_{\mathrm{ST}}=0.209, \mathrm{P}$ value $=0.001$ ), in addition to a significant and growing increase in genetic differentiation over the decades (Table 6). 
Table 6. Genetic differentiation $\left(F_{\mathrm{ST}}\right)$ among rice cultivars launched in the 1980's, 1990's, and 2000's organized in upland (Up) and irrigated (IR) groups.

\begin{tabular}{l|c|c|c|c|c|c}
\hline & Up-80 & Up-90 & Up-00 & Ir-80 & Ir-90 & Ir-00 \\
\hline Up-80 & 0 & & & & & \\
\hline Up-90 & 0.195 & 0 & & & & \\
\hline Up-00 & 0.212 & 0.319 & 0 & & & \\
\hline Ir-80 & 0.295 & 0.183 & 0.391 & 0 & & \\
\hline Ir-90 & 0.376 & 0.238 & 0.480 & 0.137 & 0 & \\
\hline Ir-00 & 0.444 & 0.411 & 0.556 & 0.240 & 0.341 & 0 \\
\hline
\end{tabular}

Based on a core set of 24 highly polymorphic SSR markers, we have determined the genetic relationship and the degree of genetic diversity among a collection of 29 rice cultivars possessing a wide variability of agromorphological and physiological traits. Together with this data, we indicated the occurrence of lower rates of admixture between irrigated and upland cultivars. The results of this study complement the phenotypical data of this important germplasm, and provide a valuable tool for use of rice breeding program.

\section{Conflicts of interest}

The authors declare no conflict of interest.

\section{REFERENCES}

Abadie T, Cordeiro CMT, Fonseca JR, Alves RBN, et al. (2005). Construção de uma coleção nuclear de arroz para o Brasil. Pesqui. Agropecu. Bras. 40: 129-136. https://doi.org/10.1590/S0100-204X2005000200005

Akagi H, Yokozeki Y, Inagaki A and Fujimura T (1996). Microsatellite DNA markers for rice chromosomes. Theor. Appl. Genet. 93: 1071-1077. https://doi.org/10.1007/BF00230127

Bonow S, Augustin E, Franco DF, Peters JA, et al. (2001). Caracterização isoenzimática de genótipos de arroz. Pesqui. Agropecu. Bras. 36: 91-300. https://doi.org/10.1590/S0100-204X2001000200012

Borba TC, Brondani RPV, Rangel PHN and Brondani C (2009). Microsatellite marker-mediated analysis of the EMBRAPA Rice Core Collection genetic diversity. Genetica 137: 293-304. https://doi.org/10.1007/s10709-009-9380-0

Borba TC, Brondani RPV, Breseghello F, Coelho ASG, et al. (2010). Association mapping for yield and grain quality traits in rice (Oryza sativa L.). Genet. Mol. Biol. 33: 515-524. https://doi.org/10.1590/S1415-47572010005000065

Breseghello F, Castro EM and Morais OP (1998). Cultivares de arroz. In: Tecnologias para o arroz de terras altas (Breseghello F and Stone LF, eds.). Embrapa Arroz e Feijão, Santo Antônio de Goiás, 41-53.

Breseghello F and Coelho ASG (2013). Traditional and modern plant breeding methods with examples in rice (Oryza sativa L.). J. Agric. Food Chem. 61: 8277-8286. https://doi.org/10.1021/jf305531j

Brondani C, Brondani RPV, Rangel PHN and Ferreira ME (2001). Development and mapping of Oryza glumaepatuladerived microsatellite markers in the interspecific cross Oryza glumaepatula x O. sativa. Hereditas 134: 59-71. https://doi.org/10.1111/j.1601-5223.2001.00059.x

Brondani RPV, Brondani C, Tarchini R and Grattapaglia D (1998). Development, characterization and mapping of microsatellite markers in Eucalyptus grandis and E. urophylla. Theor. Appl. Genet. 97: 816-827.

Brown-Guedira GL, Thompson JA, Nelson RL and Warburton ML (2000). Evaluation of genetic diversity of soybeans introductions and North American ancestors using RAPD and SSR markers. Crop Sci. 40: 815-823.

Bueno LG, Vianello RP, Rangel PHN, Utumi MM, et al. (2012). Adaptabilidade e estabilidade de acessos de uma coleção nuclear de arroz. Pesqui. Agropecu. Bras. 2: 216-226. https://doi.org/10.1590/S0100-204X2012000200010

Cabral PD, Soares TC, Lima AB, de Miranda FD, et al. (2011). Genetic diversity in local and commercial dry bean (Phaseolus vulgaris) accessions based on microsatellite markers. Genet. Mol. Res. 10: 140-149. https://doi. org/10.4238/vol10-1gmr993

Genetics and Molecular Research 16 (3): gmr16039793 
Chen X, Temnykh S, Xu Y, Cho YG, et al. (1997). Development of a microsatellite framework map providing genomewide coverage in rice (Oryza sativa L.). Theor. Appl. Genet. 95: 553-567. https://doi.org/10.1007/s001220050596

Cheng A, Mayes S, Dalle G, Demissew S, et al. (2017). Diversifying crops for food and nutrition security - a case of teff. Biol. Rev. Camb. Philos. Soc. 92: 188-198. https://doi.org/10.1111/brv.12225

Earl DA and VonHoldt BM (2012). Structure harvester: a website and program for visualizing STRUCTURE output and implementing the Evanno method. Conserv. Genet. Resour. 4: 359-361. https://doi.org/10.1007/s12686-011-9548-7

Evanno G, Regnaut S and Goudet J (2005). Detecting the number of clusters of individuals using the software STRUCTURE: a simulation study. Mol. Ecol. 14: 2611-2620. https://doi.org/10.1111/j.1365-294X.2005.02553.x

Flajoulot S, Ronfort J, Baudouin P, Barre P, et al. (2005). Genetic diversity among alfalfa (Medicago sativa) cultivars coming from a breeding program, using SSR markers. Theor. Appl. Genet. 111: 1420-1429. https://doi.org/10.1007/ s00122-005-0074-4

Guichoux E, Lagache L, Wagner S, Chaumeil P, et al. (2011). Current trends in microsatellite genotyping. Mol. Ecol. Resour. 11: 591-611. https://doi.org/10.1111/j.1755-0998.2011.03014.x

IRRI (2017), International Rice Research Institute. Available at [www.irri.org].

Menezes IPP, Barroso PAV, Hoffmann LV, Lucena VS, et al. (2010). Genetic diversity of mocó cotton (Gossypium hirsutum race marie-galante) from the northeast of Brazil: implications for conservation. Botany 88: 1-9.

Mir RR, Kumar J, Balyan HS and Gupta PK (2012). A study of genetic diversity among Indian bread wheat (Triicumaestivum L.) cultivars released during last 100 years. Genet. Resour. Crop Evol. 59: 717-726. https://doi.org/10.1007/s10722$\underline{011-9713-6}$

Miranda GV, Coimbra RR, Godoy CL, Souza LV, et al. (2003). Potencial de melhoramento e divergência genética de cultivares de milho-pipoca. Pesqui. Agropecu. Bras. 38: 681-688. https://doi.org/10.1590/S0100-204X2003000600003

Panaud O, Chen X and McCouch SR (1996). Development of microsatellite markers and characterization of simple sequence length polymorphism (SSLP) in rice (Oryza sativa L.). Mol. Gen. Genet. 252: 597-607.

Peakall R and Smouse PE (2012). GenAlEx 6.5: genetic analysis in Excel. Population genetic software for teaching and research--an update. Bioinformatics 28: 2537-2539. https://doi.org/10.1093/bioinformatics/bts460

Pereira HS, Santos JB, Souza TP and Lima IA (2008). Seleção fenotípica e assistida por marcadores moleculares de famílias de feijoeiro-comum com alta produtividade. Pesqui. Agropecu. Bras. 43: 1551-1558. https://doi.org/10.1590/S0100204X2008001100014

Pereira JJ and Cruz CD (2003). Comparação de métodos de agrupamento para o estudo da diversidade genética de cultivares de arroz. Rev. Ceres 50: 41-60.

Pritchard JK, Stephens M and Donnelly P (2000). Inference of population structure using multilocus genotype data. Genetics 155: 945-959.

Qi-Lun Y, Ping F, Ke-Cheng K and Guang-Tang P (2008). Genetic diversity based on SSR markers in maize (Zea mays L.) landraces from Wuling mountain region in China. J. Genet. 87: 287-291. https://doi.org/10.1007/s12041-008-0046-y

Rangel PN, Brondani RPV, Coelho ASG, Rangel PHN, et al. (2007). Comparative linkage mapping of Oryza glumaepatula and Oryza sativa interspecific crosses based on microsatellite and expressed sequence tag markers. Genet. Mol. Biol. 30: 614622. https://doi.org/10.1590/S1415-47572007000400019

Santos AB, Stone LF and Vieira NRA (2006). A cultura do arroz no Brasil. 2nd edn. Embrapa Arroz e Feijão, Brazil.

Silva EF, Montalván R and Ando A (1999). Genealogia dos cultivares brasileiros de arroz de sequeiro. Bragantia 2: 281286. https://doi.org/10.1590/S0006-87051999000200007

Soares PC, Soares AA, Morais OP, Castro EM, et al. (2004). Cultivares de arroz de terras altas e de várzeas recomendadas para Minas Gerais. Informe Agropecuário. 222: 24-33.

Temnykh S, Park WD, Ayres N, Cartinhour S, et al. (2000). Mapping and genome organization of microsatellites in rice (Oryza sativa L.). Theor. Appl. Genet. 100: 697-712. https://doi.org/10.1007/s001220051342

Zeng D, Tian Z, Rao Y, Dong G, et al. (2017). Rational design of high-yield and superior-quality rice. Nat. Plants 3: 17031. https://doi.org/10.1038/nplants.2017.31

Yap R, Hsu YC, Wu YP, Lin YR, et al. (2016). Multiplex PCR genotype for five bacterial blight resistance genes applied to marker-assisted selection in rice (Oryza sativa). Plant Breed. 135: 309-317. https://doi.org/10.1111/pbr.12368

Yu P, Yuan X, Xu Q, Wang C, et al. (2013). Genetic structure and Indica/Japonica component changes in major inbred rice varieties in China. Rice Sci. 20: 39-44. https://doi.org/10.1016/S1672-6308(13)60106-7

Wei Z, Hu W, Lin Q, Cheng X, et al. (2009). Understanding rice plant resistance to the Brown Planthopper (Nilaparvata lugens): a proteomic approach. Proteomics 9: 2798-2808. https://doi.org/10.1002/pmic.200800840

Genetics and Molecular Research 16 (3): gmr16039793 